\section{Exclusive breast feeding and prevention of diarrheal diseases. A study in Qatar}

\section{Aleitamento materno exclusivo na prevenção de doenças diarréicas. Um estudo realizado no Qatar}

Abdulbari Bener 1

Mohammad S. Ehlayel 2

Hatim M. Abdulrahman 3

1 Department of Medical Statistics \& Epidemiology. Hamad Medical Corporation and Weill Cornell Medical College. PO Box 3050. Doha- State of. Qatar. E-mail: abener@hmc.org.qa

2 Department of Pediatrics Allergy and Immunology. Hamad Medical Corporation. Qatar

3 Department of Pediatrics. Gastroentrology Unit. Hamad Medical Corporation. Qatar

\begin{abstract}
Objectives: to explore the relationships between breast feeding and diarrhea and to assess the effect of exclusive breast feeding $(E B F)$ on reducing the risk of diarrhea in Qatar.

Methods: this is a cross sectional survey carried out at the Well baby clinics and Pediatric clinics in the 11 Primary Health Care Centers and Hamad General Hospital, Hamad Medical Corporation, in Qatar. A multistage sampling design was used and a representative sample of 1500 Qatari infants and pre-school children with an age range of 0-3 years and mothers aged between 18 to 47 years were surveyed during the period from October 2006 to September 2008 in Qatar. Out of the 1500 mothers, 1278 agreed to participate in this study, with a response rate of $85.2 \%$. Questionnaires were administered to women who were attending Primary Health Care (PHC) Centers for child immunization. Data about the child gathered included date of birth, gender, birth order, consanguinity, socio-economic conditions, age of mother, level of education of mother, occupation, mode of breast feeding, sterilization of bottle and incident of diarrhea during the interview. Univariate statistical methods were performed for statistical analysis.

Results: of the 1278 infants studied, more than half (59.3\%) were exclusively breastfed, and the mean duration was $11.4(S D=6.7)$. The risk for presenting diarrhea was higher in formula fed (48.7\%) and partially breastfed children (37.3\%) when compared to EBF $(32.5 \%)$.

Conclusions: EBF plays an important role in reducing the incidence and severity of infantile diarrhea. Key words Breast feeding, Diarrhea, infantile, Risk factors, Qatar
\end{abstract}

\title{
Resumo
}

Objetivos: investigar a relação entre a amamentação e a diarréia e avaliar o efeito do aleitamento maternao exclusivo (AME) na redução do risco de diarréia no Qatar.

Métodos: um estudo transversal realizado nos Well Baby Clinics and Pediatric Clinics dos 11 centros de atenção básica do Hamad General Hospital, Hamad Medical Corporation, no Qatar. Um desenho amostral de múltiplos estágios foi empregado com uma amostra representativa de 1500 recém-nascidos e crianças de idade pré-escolar catarianos entre outubro de 2006 e setembro de 2008 no Qatar. Entre as 1500 mães, 1278 aceitaram participar neste estudo, uma taxa de resposta de $85,2 \%$. Os questionários foram aplicados a mulheres atendidas pelos centros de atenção básica para imunização infantil. Dados colecionados sobre as crianças incluíram data de nascimento, gênero, ordem de nascimento, consanguinidade, condições socioeconômicas, idade maternal, escolaridade maternal, ocupação maternal, método de amamentação, esterilização dos biberões, e incidência de diarréia durante a entrevista. Métodos univariados e foram utilizados para realizar a análise estatística.

Resultados: dos 1278 recém-nascidos estudados, mais que metade (59.3\%) foram exclusivamente amamentados e a duração média foi de 11,4 (DP=6,7). O risco de apresentar a diarréia foi mais alto nas crianças aleitadas com fórmulas (48.7\%) e nas que foram parcialmente amamentadas (37.3\%) em comparação com a AME $(32.5 \%)$.

Conclusões: o AME desempenha um papel importante na redução da incidência e da gravidade da diarréia infantil.

Palavras-chave Aleitamento materno, Diarréia infantil, Fatores de risco, Qatar 


\section{Introduction}

In developing countries breast feeding reduces the incidence and severity of diarrhea in infants, ${ }^{1-3}$ although this effect may be less pronounced in areas with better water supply and sanitation facilities. ${ }^{4}$ Modern water supply and sanitation facilities are also thought to at least partly explain the absence of protection by exclusive breast feeding (EBF) against infantile diarrhea seen in some studies in developing countries. $2,3,5$

There is ample evidence of a positive influence of breastfeeding, especially exclusive breast feeding on diarrhea. Yoon et al. ${ }^{6}$ reported a higher risk of diarrhea mortality associated with not breast feeding. A similar pattern has also been reported in other studies.3-5 In a recent meta-analysis of data from six developing countries, breast feeding provided a greater degree of protection against diarrhea attributable to acute respiratory infection in the first six months of life, whereas the level of protection was similar for infants who were 6 to 11 months of age. 1 The World Health Organization (WHO) 1 recommends six months of EBF for all infants. In developing countries, exclusive breast feeding has a large protective effect on infant mortality and severe morbidity.2-3 The objectives of the current study were to explore the relationship between breast feeding and diarrhea and to assess the effect of exclusive breast feeding on reducing the risk of diarrhea.

\section{Methods}

The infant and pre-school children studied were the subjects of this cross-sectional population study conducted in Qatar. The potential subjects were all male and female children aged 0-3 years and their mothers visiting the child immunization centers at the Primary Health (PHC) Centers. The study was carried out at the Well Baby clinics in the 11 PHC Centers of the Hamad Medical Corporation, in Qatar. The PHC sample was adjusted proportionally for each clinic on the basis of the daily visits for immunization and well baby clinics by way of a systematic sampling technique. A multistage sampling design was used and a representative sample of 1500 infants and pre-school children in the age range of 0 3 years and mothers aged between 18 to 47 years were surveyed during the period from October 2006 to September 2008 in Qatar. A total of 1278 mothers $(85.2 \%)$ agreed to participate in this study.

Questionnaires were administered to women who were attending PHC Centers for child immu- nization. Data on the child collected included date of birth, gender, birth order, consanguinity, socioeconomic conditions, age of mother, level of education of mother, occupation, mode of breast feeding, sterilization of bottle and incidence of diarrhea during the interview.

Diarrhea was defined as the presence of three or more liquid or semi-liquid stools per day accompanied or not by blood, mucus or fever. The total number had to exceed the usual number of daily bowel movements. An incidence diarrhea in the child was defined by the mother as the onset of stools that were more frequent and/or fluid than normal. The end of a diarrheal episode in the child was defined by the mother as the point when both the frequency and fluidity of stools reverted to normal.

The data were entered into a computer and processed using the Statistical Packages for Social Sciences (SPSS) version 18. The Student -t test, Chisquare and Fisher exact test were performed appropriately. The level $p<0.05$ was considered as the cutoff value for significance.

\section{Results}

Of the 1278 infants studied, more than half (59.3\%) were exclusively breast fed, while $28.3 \%$ were partially breast fed and $12.4 \%$ were formula fed. The mean duration of EBF was $11.4(\mathrm{SD}=6.7)$. Table 1 shows the socio-demographic characteristics of diarrhea morbidity in the children studied. Out of 1278 infants, 458 (35.8\%) had episodes of diarrhea. The risk of presenting diarrhea was higher and statistically significant in male children $(55.5 \%, p=0.002)$ and when the mother had a high level of education $(p<0.05)$. The risk for presenting diarrhea was higher and statistically significant in children who were formula fed $(48.7 \%)$ when compared to those who were exclusively breast fed, as it was for partially breastfed children $(37.3 \%)(p<0.001)$ (Figure 1). 
Socio-demographic characteristics and prevalence of episodes of diarrhea in children surveyed $(\mathrm{N}=1278)$.

\begin{tabular}{|c|c|c|c|c|c|}
\hline \multirow[t]{3}{*}{ Characteristic } & \multicolumn{4}{|c|}{ Episodes of diarrhea } & \multirow[t]{3}{*}{$p^{*}$} \\
\hline & \multicolumn{2}{|c|}{ Yes } & \multicolumn{2}{|c|}{ No } & \\
\hline & $\mathrm{n}$ & $\%$ & $\mathrm{n}$ & $\%$ & \\
\hline Child's age (years) & & & & & 0.021 \\
\hline$<1$ & 77 & 16.8 & 100 & 21.6 & \\
\hline $1-2$ & 281 & 61.47 & 286 & 61.8 & \\
\hline$>2$ & 100 & 21.7 & 77 & 16.6 & \\
\hline Child's gender & & & & & 0.002 \\
\hline Male & 254 & 55.5 & 378 & 46.1 & \\
\hline Female & 204 & 44.5 & 442 & 53.9 & \\
\hline Child's birth order & & & & & NS \\
\hline $1-2$ & 215 & 46.9 & 393 & 47.9 & \\
\hline $3-4$ & 168 & 36.7 & 311 & 37.9 & \\
\hline $5-8$ & 75 & 16.4 & 116 & 14.1 & \\
\hline Parental consanguinity & & & & & NS \\
\hline Yes & 171 & 37.3 & 278 & 33.9 & \\
\hline No & 287 & 62.7 & 541 & 66.1 & \\
\hline Age group of mother (years) & & & & & NS \\
\hline$<25$ & 104 & 22.7 & 225 & 27.4 & \\
\hline $25-34$ & 282 & 61.6 & 469 & 57.2 & \\
\hline$\geq 35$ & 72 & 15.7 & 126 & 15.4 & \\
\hline Level of education of mother & & & & & 0.05 \\
\hline University & 91 & 19.9 & 150 & 18.3 & \\
\hline High School & 204 & 44.5 & 313 & 38.2 & \\
\hline Secondary School & 55 & 12.0 & 140 & 17.1 & \\
\hline Primary School & 45 & 9.8 & 94 & 11.5 & \\
\hline Illiterate & 63 & 13.8 & 123 & 15.0 & \\
\hline Mother's occupation & & & & & NS \\
\hline House wife & 324 & 70.7 & 600 & 73.2 & \\
\hline Professional & 96 & 21.0 & 151 & 18.4 & \\
\hline School Teacher & 32 & 7.0 & 57 & 7.0 & \\
\hline Police / Security Officer & 6 & 1.3 & 12 & 1.4 & \\
\hline Family income (U\$/month) & & & & & NS \\
\hline Low $(<2,750)$ & 103 & 22.5 & 198 & 24.1 & \\
\hline Medium $(2,750-4,130)$ & 221 & 48.3 & 422 & 51.5 & \\
\hline High $(>4,130)$ & 134 & 29.3 & 200 & 24.4 & \\
\hline Accommodation type & & & & & NS \\
\hline Villa-semi villa & 213 & 46.5 & 399 & 48.7 & \\
\hline Traditional house & 77 & 16.8 & 123 & 15.0 & \\
\hline Apartment flat & 168 & 36.7 & 298 & 36.3 & \\
\hline \multicolumn{6}{|l|}{ Breast feeding mode } \\
\hline Exclusive breast feeding & 246 & 53.7 & 512 & 62.4 & 0.003 \\
\hline Partial breast feeding-mixed & 135 & 29.5 & 227 & 27.7 & NS \\
\hline Formula feeding & 77 & 16.8 & 81 & 9.9 & $<0.001$ \\
\hline Total & 458 & 35.8 & 820 & 64.2 & \\
\hline
\end{tabular}

* $\chi^{2}$ test except for Mother's occupation ( $F$ is her exact tes $t$ ); NS = not significant. 
The effect of breast feeding mode on diarrhea.

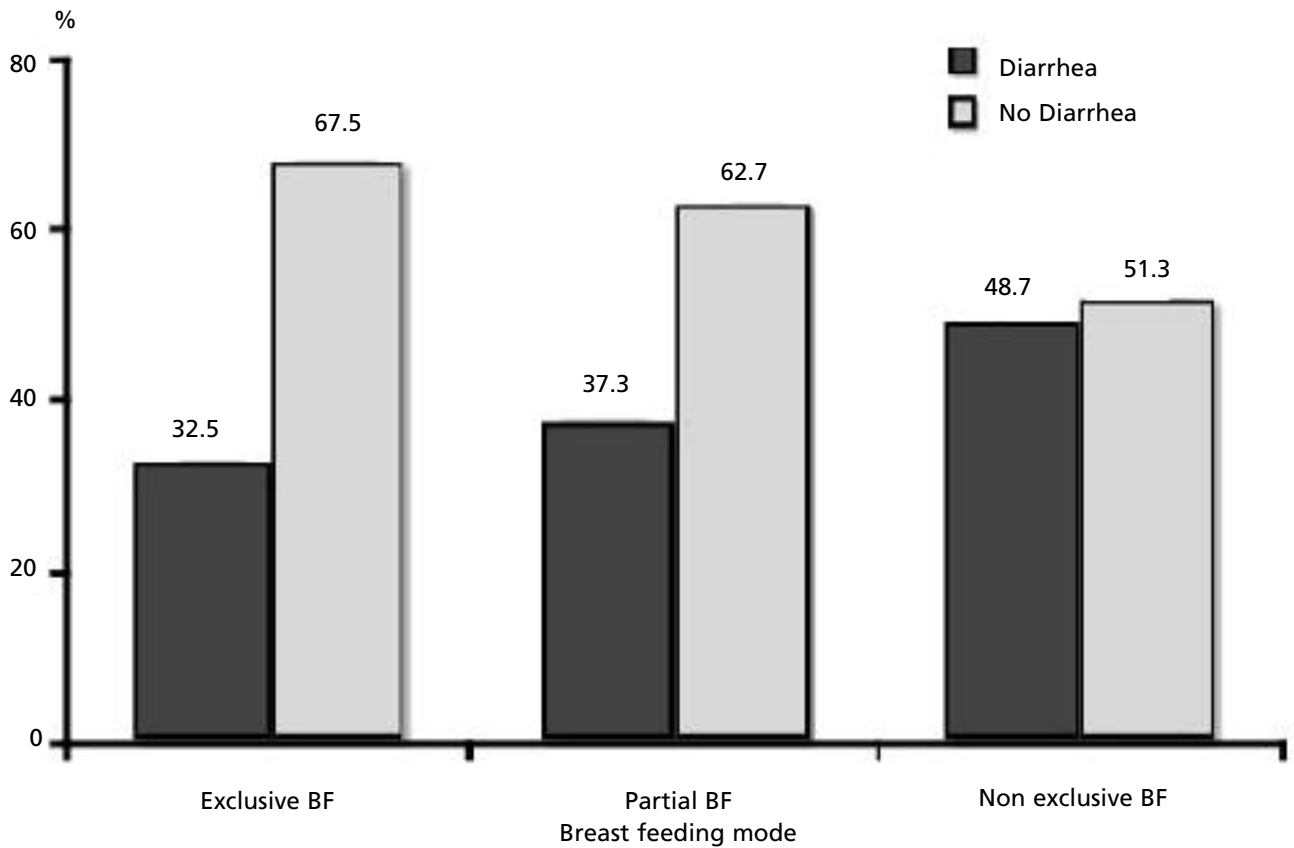

$\chi^{2}(\mathrm{df}=2) ; p<0.008$.

$\mathrm{BF}=$ breast feeding.

Exclusive BF $\quad: p<0.001$

Partial BF $: p<0.001$

Non exclusive BF : NS

\section{Discussion}

Despite the universal access to modern water supply and sanitation facilities, in Qatar, we detected a substantial positive association between breast feeding and diarrhea in a study of children aged between 0 and 3 years. These results confirm the protective effect of exclusive breast feeding against morbidity related to infectious diseases in infancy. $6-8$ The results show that children aged 0-3 years who are exclusively breast fed are less likely to suffer from diarrhea than infants who were not exclusively breastfed. The results are consistent with those of other studies on the association between mode of feeding and diarrhea morbidity in children. ${ }^{9-10}$

The high prevalence of diarrhea (35.8\%) among children in Qatar might be because of its demographic profile. ${ }^{11}$ In Qatar, approximately $70 \%$ of the population is made up of expatriates, mostly Asians, and they are unaware of the travel-related infectious diseases they may have picked up when visiting their home countries. This can lead to imported diarrheal diseases. The risk of diarrhea was significantly higher in boys. Qatar's small population has helped guarantee a high per capita income and most of the population earns a reasonably good monthly income. Furthermore, expatriates pay a very nominal fee for health care services. This may be the reason for the lack of significant influence of family income on the occurrence of episodes of diarrhea.

Studies in developing countries have found variability in the effect of breast feeding. In studies of diarrhea in some developing countries, such as in India, ${ }^{2}$, Nigeria, ${ }^{4}$ Malaysia, ${ }^{7}$ the Philippines, ${ }^{6}$ and Sri Lanka, 10 it has been reported that breast feeding has a stronger protective effect against diarrhea. Similarly, in Bangladesh, it has been shown that breastfeeding has effectively combated diarrhea following a community-based health education campaign. $3,8,9$ A study in Malaysia7 found that formula feeding had a much stronger effect on mortality in infants living in households without 
piped water or a toilet than in households with toilets.

More recently a study by Quigley et al.12 reported that breast feeding, particularly when exclusive and prolonged, protects against severe morbidity in the United Kingdom. A populationlevel increase in exclusive, prolonged breast feeding would be of considerable potential benefit for public health. Our findings are consistent with previous observations of a negative relation between breast feeding and diarrheal morbidity in children in areas with modem water supply and sanitation facilities. ${ }^{10,13}$ Finally, the mechanisms through which breast feeding may protect children against diarrhea are well known. ${ }^{6-10}$

Promotion of exclusive breast feeding in the first 4 to 6 months of life and reductions both in the incidence of diarrhea and related deaths are likely to be beneficial for infant survival in this population. This is consistent with earlier estimates of potential reductions in diarrhea mortality after increased breast feeding. $6-8$ Estimates indicate that infant mortality could be reduced by almost one third if the

\section{References}

1. WHO (World Health Organization). Collaborative study team on the role of breast feeding on the prevention of infant mortality effect of breast feeding on infant and child mortality due to infectious diseases in less developed countries: a pooled analysis. Lancet. 2000; 355: 451-5.

2. Bhandari N, Bahl R, Mazumdar S, Martines J, Black RE, Bhan MK (Infant Feeding Study Group). Effect of community-based promotion of exclusive breastfeeding on diarrhoeal illness and growth: a cluster randomised controlled trial. Lancet. 2003; 361: 1418-23.

3. Haider R, Islam A, Hamadani J, Amin NJ, Kabir I, Malek MA, Mahalanabis D, Habte D. Breast-feeding counselling in a diarrhoeal disease hospital. Bull World Health Organ. 1996; 74: 173-9.

4. Oni GA. Infant feeding practices, socio-economic conditions and diarrhoeal disease in a traditional area of urban Ilorin, Nigeria. East Afr Med J. 1996; 73: 281-2.

5. Quigley MA, Cumberland P, Cowden JM, Rodrigues LC. How protective is breast feeding against diarrhoeal disease in infants in 1990s England? A case-control study. Arch Dis Child. 2006; 91: 245-50.

6. Yoon PW, Black RE, Moulton LM, Becker S Effect of not breastfeeding on the risk of diarrhoeal and respiratory mortality in children under 2 years of age in Metro Cebu, The Philippines. Am J Epidemiol. 1997; 143: 1142-8.

7. Knight SM, Toodayan W, Caique WC, Kyi W, Barnes A, prevalence of exclusive breast feeding in the first four months of life could be raised to nearly $80 \%$, with smaller gains with intermediate improvements in breast feeding practices. Recent studies in Bangladesh have shown that such improvements in breast feeding practices can be achieved through community-based interventions. ${ }^{8,9}$ Furthermore, a study conducted in Brazil13 has shown that the likelihood of presenting diarrhea was $64 \%$ higher in children younger than six months who were not breastfed compared with those who were. Exclusive breast feeding and partial breast feeding are a protective factor against diarrhea in the first six months of life. This is confirmed by the present survey carried out in Qatar.

\section{Acknowledgments}

This study was funded, in part, by a research grant from MSD, Merck Research Laboratories, NJ, USA and supported by the Research Committee of Hamad Medical Corporation, Qatar.
Desmarchelier P. Risk factors for the transmission of diarrhoea in children: a case-control study in rural Malaysia. Int J Epidemiol. 1992; 21: 812-8

8. Arifeen SE, Black RE, Antelman G, Baqui AH, Caulfield L, Becker S. Exclusive breast feeding reduces acute respiratory infection and diarrhoea deaths among infants in Dhaka slums. Pediatrics. 2001; 108: 67-74.

9. Mihrshahi S, Ichikawa N, Shuaib M, Oddy W, Ampon R, Dibley MJ, Kabir AK, Peat JK. Prevalence of exclusive breast feeding in Bangladesh and its association with diarrhoea and acute respiratory infection: results of the multiple indicator cluster survey 2003. J Health Popul Nutr. 2007; 25: 95-204.

10. Perera BJ, Ganesan S, Jayarasa J, Ranaweera S. The impact of breastfeeding practices on respiratory and diarrhoeal disease in infancy: a study from Sri Lanka. J Trop Pediatr. 1999; 45: 115-8.

11. Ehlayel MS, Bener A, Abdulrahman HM. Protective effect of breastfeeding on diarrhoea among children in a rapidly growing newly developed Society. Turk J Pediatr. 2009; 51: 527-33.

12. Quigley MA, Kelly YJ, Sacker A. Breast feeding and hospitalization for diarrheal and respiratory infection in the United Kingdom Millennium Cohort Study. Pediatrics. 2007; 119: e837-42.

13. Vieira GO, Silva LR, Vieira TO. Child feeding and diarrhoea morbidity. J Pediatr (Rio J). 2003; 79: 449-54.

Recebido em 17 de agosto de 2010

Versão final apresentada em 9 de dezembro de 2010

Aprovado em 11 de janeiro de 2011 